\title{
The Effects of Money Supply and Interest Rates on Stock Prices, Evidence from Two Behavioral Experiments
}

\author{
Christian A. Conrad ${ }^{1}$ \\ ${ }^{1}$ University of Applied Science HTW at Saarbrücken, Germany. \\ Correspondence: Christian A. Conrad, University of Applied Science, htw saar, Waldhausweg 14, 66123 Saarbrücken, \\ Germany.
}

Received: January 16, 2021

Accepted: February 19, $2021 \quad$ Available online: February 23, 2021

doi:10.11114/aef.v8i2.5173

URL: https://doi.org/10.11114/aef.v8i2.5173

\begin{abstract}
What is the impact of interest rate and monetary policy on the stock market? Some studies find a positive impact of expansive monetary policy on stock prices others prove the opposite. This paper examines the effects of monetary expansion and interest rate changes on investment behavior on the stock market by illustrating two behavioral experiments with students. In our experiments the increase of money supply and the decrease of interest rates had a direct positive impact on share prices. These findings support the hypothesis that extreme expansive monetary policy with low, zero or negative interest rates encourage financial bubbles on the stock market. To avoid a crash the exit from such a policy must be slow. As happened in 1929, crashes can damage the financial system and the real economy. Central banks must take this into account in their monetary policy.
\end{abstract}

Keywords: stock prices, behavioral economics, money supply, interest rates, quantitative easing, expansive monetary policy, monetary business cycles, boom and bust cycles, zero interest rate policy, experimental simulation, stock market

JEL classification: E 43, E 47, E 58

\section{Introduction}

After the financial crisis and now in the Covid-19 crisis many central banks turned to quantitative easing (QE) to support economic growth. In order to reduce long-term borrowing costs they purchased massive and unprecedented amounts of long-term bonds, which created liquidity and decreased the long term borrowing costs. Some central banks even pushed short-term interest rates slightly below zero to stimulate the economy. But the slow recovery, especially in Europe, has raised questions about the benefits of $\mathrm{QE}$ bond purchases versus their detriments and whether their effectiveness has reached a limit. What is the impact of such an expansive monetary policy on the stock market? Empirical studies contradict each other. Some find a positive impact of expansive monetary policy on stock prices others prove the opposite. Against such a background this paper examines the effects of monetary expansion and interest rate changes on investment behavior on the stock market by illustrating two behavioral experiments with students. In section 2 the existing literature and studies are presented and compared to the experiment presented here. Section 3 explains the experimental design of the study. Finally, the results are presented (section 4) and the conclusions drawn (section 5).

\section{Related Literature}

\subsection{Theoretical Background}

A positive correlation between the two variables money supply and stock prices can be interpreted in three different ways. Firstly, there is an ex post correlation when the stock prices increased due to higher productivity in real economy and the central bank provided the money needed to prevent deflation. Secondly, an increase in money supply, e.g. liquidity, leads to portfolio adoptions on the part of the stockholder, to realize the desired proportion of liquidity and assets. The stockholders have more money to buy assets, which leads to an increase in stock prices providing a constant amount of stocks. Thirdly, increased money supply leads to lower interest rates and thereby lowers the discount rate on future cash flows from an enterprise's expected profits. Interest is a main part of production and investing costs of the enterprises, therefore lower interest rates means higher profits (International Monetary Fund 2000; Baks \& Kramer 1999). In addition, others argue that low interest rate policy could lead to a buildup of leverage, or asset bubbles by encouraging 
excessive risk taking by financial market participants (Conrad \& Stahl, 2002; Caruana 2013; Feldstein 2013; Stiglitz 2016). Confronted with low interest rates bank and non-bank investors may switch to excessive risk in order to compensate the smaller interest income (Hannoun, 2015). The mechanism is called "search for yield". If financial institutions have long-term commitments (such as pension funds and insurance companies) they come under pressure to earn the yield they promised on their liabilities. If they obtain only a low interest return on their assets they might be forced to go in risk (Rajan, 2005; De Nicolò, Dell'Ariccia, Laeven, \& Valencia, 2010) and purchase stocks instead of bonds. Unilaterally constructed bonus-based compensation schemes encourage excessive risk-taking and were one reason for the financial crisis (Conrad, 2015). However, only one paper examined the effects of interest rate cuts on investment behavior. This behavioral experiment with students showed that decreasing interest rates encourage risk-taking (Conrad, 2019).

The roots of the boom and bust cycle theory go back to Hayek and Wicksell. Friedrich August von Hayek holds the tremendous elasticity of the banking system and the unregulated money supply development responsible for the economy overheating (Hayek, 1976; Hayek, 1935). Knut Wicksell on the other hand, lays the blame at the doorstep of the monetary policy decision-makers and their poor decisions regarding interest controls (Wicksell, 1922; Wicksell, 1968; Grosskettler, 1989). A set interest level on the capital market below that for the supply and demand balance causes an expansion of the money supply. In specific, the exchange relation of goods to money tips in favor of money. The demand for credit increases because of the low interest level. New current account deposits come into existence through the increased credit. The speed of money circulation increases, and with it the money supply. There is a shift in portfolios, since the value of the investor's liquidity increases relative to the stocks owned. The new money flows into the stock markets and pushes the stock prices ever upwards. Because the interest functions as both an asset yield and a discount factor it brings about an artificial interest reduction in an upswing of the stock price as well as an excessive resource allocation in stock value. This effect can cause the system to overheat. The higher stock prices signify profit potential and represent security to the banks that allows them to grant credit and thus indirectly create money. A self-propagating upward movement is created on the stock market, which supports a boom through excessive liquidity supply from the central banks. Should the interest rate decreases be reversed by the central bank this can of course lead to the same effect in the other direction (Conrad, 2000).

\subsection{Empirical Studies}

There are empirical studies about the impact of interest rates on stock market prices. According to Thorbecke (1997), stock prices decline by $0.8 \%$ if federal funds rate increases unexpectedly by $1 \%$. Rigobon and Sack (2004) estimated that stock index S\&P 500 loses $1.7 \%$ because of 3-month rate increases of $0.25 \%$ and found a higher effect for Nasdaq index (2.4\% decrease).

Trust Kganyago and Victor Gumbo tested the long-term relationship between money market interest rates and stock market returns in Zimbabwe from April 2009 to December 2013. The estimation model controls for money supply growth rate, inflation, volume of manufacturing index, crude oil price and political stability. They found evidence of a strong and statistically significant inverse causal relationship between money market interest and stock market returns (Kganyago \& Gumbo, 2015).

The relationship between money supply development and asset prices has been examined in several empirical studies. Using the increase in Japanese stock, art and real estate prices in the second half of the 1980s as an example, empirical studies have shown that the catalyst for the bubble was an expansive monetary policy in conjunction with a productivity increase in the Japanese economy and an higher demand for real estate in Tokyo; all of which expressed itself in more credit given by the banks (Ito \& Iwaisako, 1995). In the first half of the 1990s the prices mostly fell back to their original level. Ito und Iwaisako (1995) establish further, that the increase in prices can be explained with fundamental changes in data only until 1987, at which point the bubble took on a life of its own. By Homa and Jaffee (1971) had already found a significant and systematic relationship between stock prices and money supply as represented by deposits and currency. Rozeff (1974) showed that both money supply and M1 aggregate can impact stock prices. A finding which was later supported by Flannery and Protopapadakis (2002). Lastrapes (1998) estimates that stock prices fall off by $2.4 \%$ if M1 is reduced by $1 \%$. Safar and Siničáková (2017) prove statistically significant influence of money supply on stock market indices in the US and EU. Pícha (2017) found an influence of money supply on valuation of S\&P 500 indices with a 6 month lag. According to the International Monetary Fund further analyses show a positive correlation between the variables money supply and stock prices (International Monetary Fund, 2000; Baks \& Kramer, 1999). However, other studies have come to contradictory conclusions. Black (1987) found that changes in money supply do not influence stock prices. Campbell and Ammer (1993) came to the conclusion that money supply has only minimal effect on stocks prices.

How can these controversial findings be explained? We have fundamental method problems here. The scientific content of the predominantly Granger-based econometric studies has to be questioned. Because of the risk of false results, the 
Granger test is discouraged if the variables under study are extremely volatile (Irwin \& Sanders, 2012). For highly volatile variables such as stock prices, a lack of covariance stationarity was found, which does not provide a condition for the regression of time series (Pagan \& Schwert, 1990; Phillips \& Loretan, 1990; Frenk, 2011; Schlecker 2014; Conrad, 2020). Due to innumerable influencing factors on supply and demand, we have a strong multi-causality here in which the individual influencing factors cannot be filtered out precisely. If causal variables are not extracted, Granger tests can show correlations that are not present (spurious regression). The same applies to purely random correlations, which may arise in particular in the case of short observation periods or incorrect time intervals (Frenk, 2011).

Against this background, we decided to analyze the relationship between money, interest rate and stock markets with a behavioral experiment as an alternative scientific method. This should give additional evidence.

\section{Experimental Design}

We want to answer two questions:

A. How does the investor react on the stock market if the money supply is changed? Some studies find a positive impact of expansive monetary policy on stock prices while others prove the opposite. However, as most studies show a positive impact we use this as hypothesis.

B. How do the investors react on the stock market if the save interest rate of bonds as an alternative investment is changed and how is the profit of the stock market companies, and therefore also the dividends influenced by the interest rate as cost of borrowed capital? We test the assumption of the portfolio-theory that not only risk but also yield is decisive for the allocation of invested capital.

The purpose of this paper is to test the hypothesis that:

A. an increase of money supply leads to higher share prices and encourages bubbles with a subsequent crash when money supply is reduced (boom and bust cycle).

B. interest rates influence capital allocation as per the portfolio-theory that capital follows the yield. Thus, bonds are the alternative of shares and vice versa. A decrease in the interest rate should therefore lead to higher share prices and vice versa. Interest rates also influence the cost of capital borrowed from the enterprises. Therefore, lower interest rates lead to higher profits and dividends.

How do the money supply and interest rates affect investment behavior? The methodology was to simulate investment decision making on the stock market under different money supply and interest rates. We conducted two experiments, A and B:

Two experiments, A and B, were conducted in the winter semester of 2019/20 with different groups but were terminated due to the Covid 19 pandemic. There were 56 participants in game A and 43 students in game B, who came from different Business Bachelor courses at the University of Applied Science HTW at Saarbrücken, Germany. Most investment capital is controlled and allocated by agents for third persons. There are family offices, investment firms, fund managers and the managers of companies. The task was to invest capital like an investment agent or a manager of a company. The participants were asked to maximize the profit as it is the obligation of a manager as agent for a principal (company owner resp. shareholder). Maximal profit in the group resulted in $10 €$ real money as variable compensation. The rules were explained to the students before starting the experiment. The students were asked to check each other's calculations after each game.

\section{Game A: Money supply and stocks}

Game A aimed to examine how money supply affects the demand for stocks. Apart from stocks, there was only the alternative of holding money as liquidity without interest. The shares did not distribute any dividends.

Students were to invest their money in stocks or hold cash. Ten shares in the fictional corporation Rancom LC with a nominal value of $€ 100$ each were added per round. The shares were auctioned every round. The students were informed of the additional amount of money that they had at their disposal each round as a result of the monetary policy of the central bank. They could sell or buy the shares through the lecturer who would auction them off (stock exchange). The highest bids were accepted. The respective maximum price was set as the share price. Sales were served first and settled according to the available bids. Up to round 5 the money supply was doubled. The last two rounds it stayed the same.

\section{Game B: Interest rate and stocks}

Game B aimed to examine how interest rates affect the stock's attractiveness as an alternative investment. Two factors affect the investor here. On the one hand, the interest rate is the return on bonds as safe investment, and on the other, it determines the cost of debt and thus also the profit and dividend of the stock corporation. Students were to invest their money in stocks or fixed deposits. There was an initial stock of 0 shares in Rancom LC with a nominal value of $€ 300$ ( $€ 300$ equity and $€ 600 \mathrm{debt}$ ). Each round, $€ 1,000$ were added per player and 10 shares were auctioned off so that stocks 
and money increased roughly proportionally. The return on capital employed was a constant $€ 60$, or $6.67 \%$. The interest rates, which the central bank set as the base rate, were communicated to the students every round. Likewise, the price to earnings ratio and the dividends changed every round in accordance with the change in the cost of debt of Rancom AG. Representing the earnings situation, the students were informed of the dividend yield as a 50\% distribution of the profit. Students could invest an amount of money at the relevant interest rate, or sell or buy the shares through the lecturer who would auction them off. The highest bids were accepted. The respective maximum price was set as the share price. Sales were served first and settled according to the available bids. At the end of each round the interest and dividends were added as yield to the invested capital.

These simple experiments show clear results.

\section{Results}

\section{Game A: amount of money and stocks}

Figure 1 shows the development of the money supply and the average bid as share prices and figure 2 the development of the liquidity on hand (which is the average cash held by the students at the end of each round) and the average share bids of the students. We can see a positive relation between money and share price. In addition, the mere stop of monetary expansion in round 5 created a stock market crash if we look at the average bids which would be relevant for the stock market development. Starting in round 5 we see a slow reaction of the bids. Even though the money supply drops the bids first stay high.

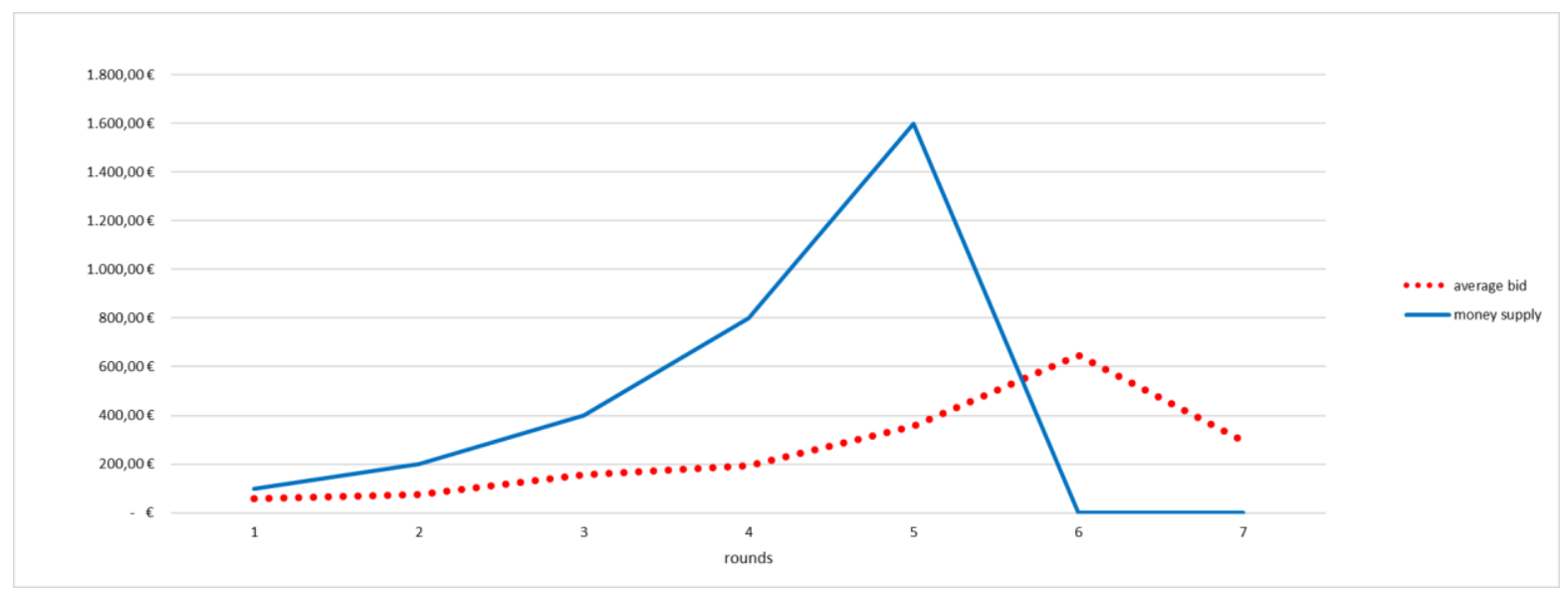

Figure 1. Money supply and average bid

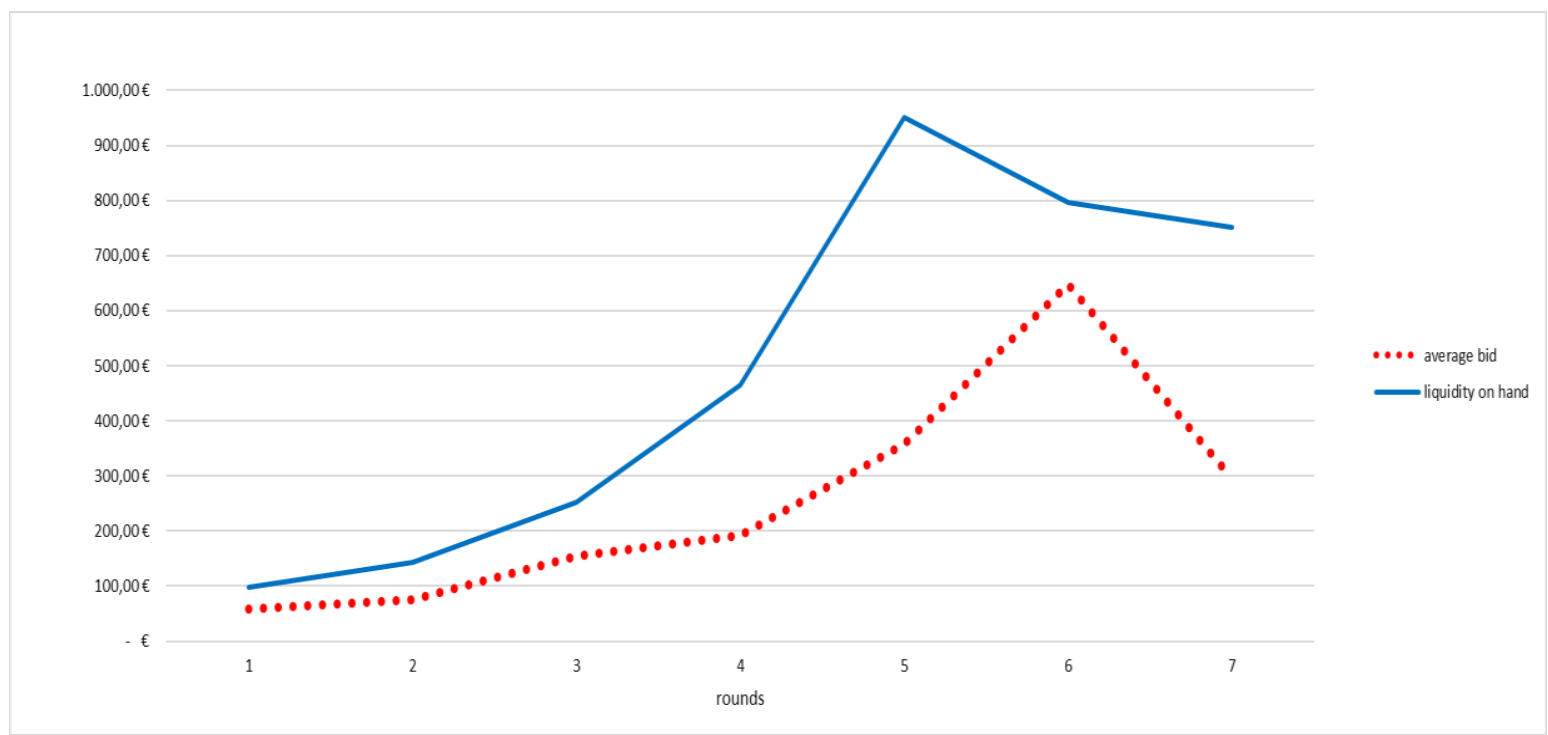

Figure 2. Liquidity on hand and average share bids 


\section{Conclusion game A}

In our experiment money supply had a direct positive impact on share prices. The hypothesis was not disproven and seems to be true. Central banks have a strong responsibility for the stock market if they increase the money supply disproportionately to the real production. If there has been an expansive monetary policy followed by increasing stock prices, the exit of this policy must be done slowly, otherwise a crash might follow.

\section{Game B: interest rate and stocks}

The interest rates were first decreased and then increased (see figure 3). The dividends were adapted according to the changed-borrowing cost of Rancom LC due to the changes in the interest rate (figure 4), also the price to earning ratios were adapted (figure 5).

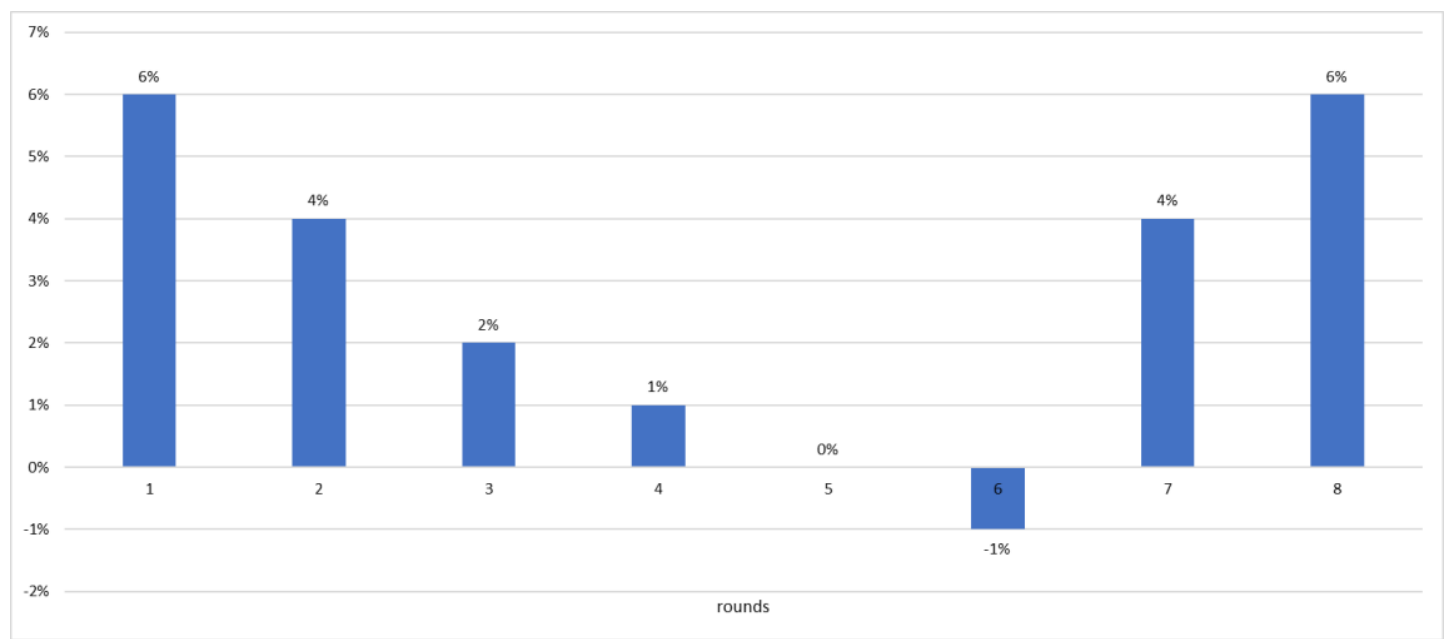

Figure 3. Interest rates

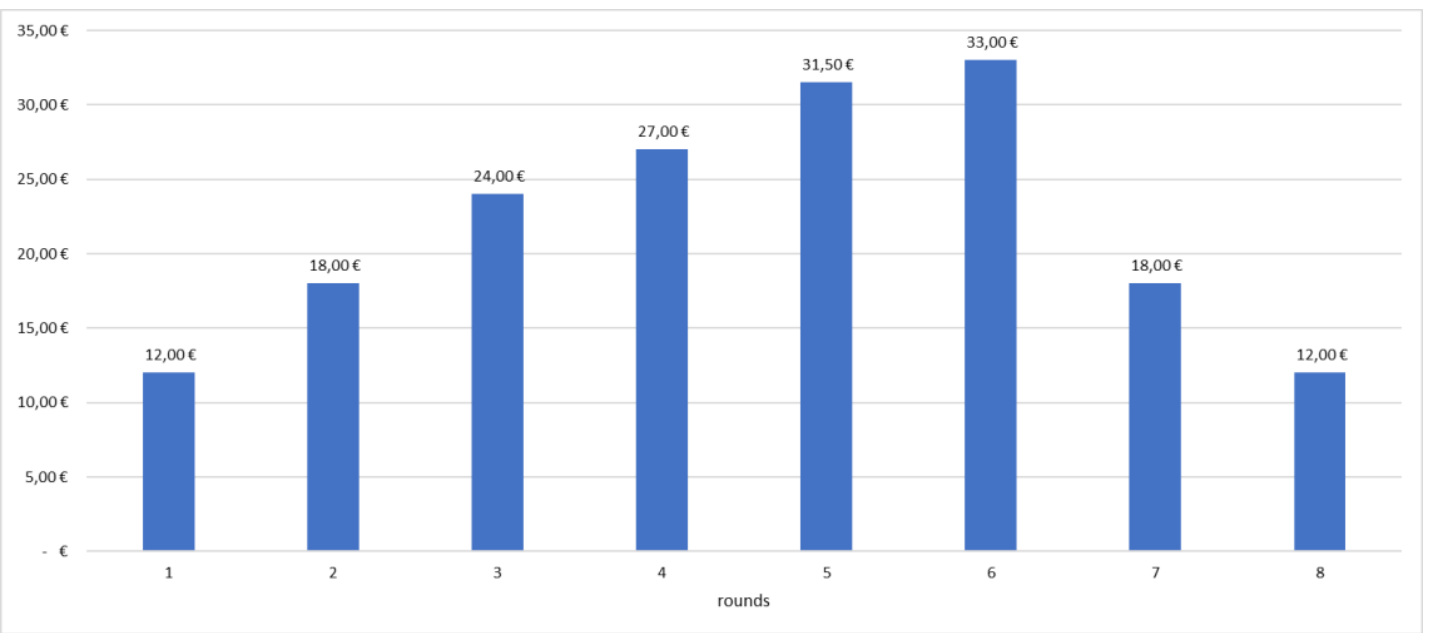

Figure 4. Dividends

Share prices were clearly driven by the interest rate reduction, which resulted in higher earnings and dividends (figure 4). The students adjusted their portfolio according to the changed yield relation between shares and fixed deposits even though the shares were more risky. The sharp increase in interest rates in round 7 led to a stock market crash (see figure 5) due to quick portfolio adjustments (see figure 6). And the crash resulted in a strong decrease of the asset value of shares (see figure 7). 


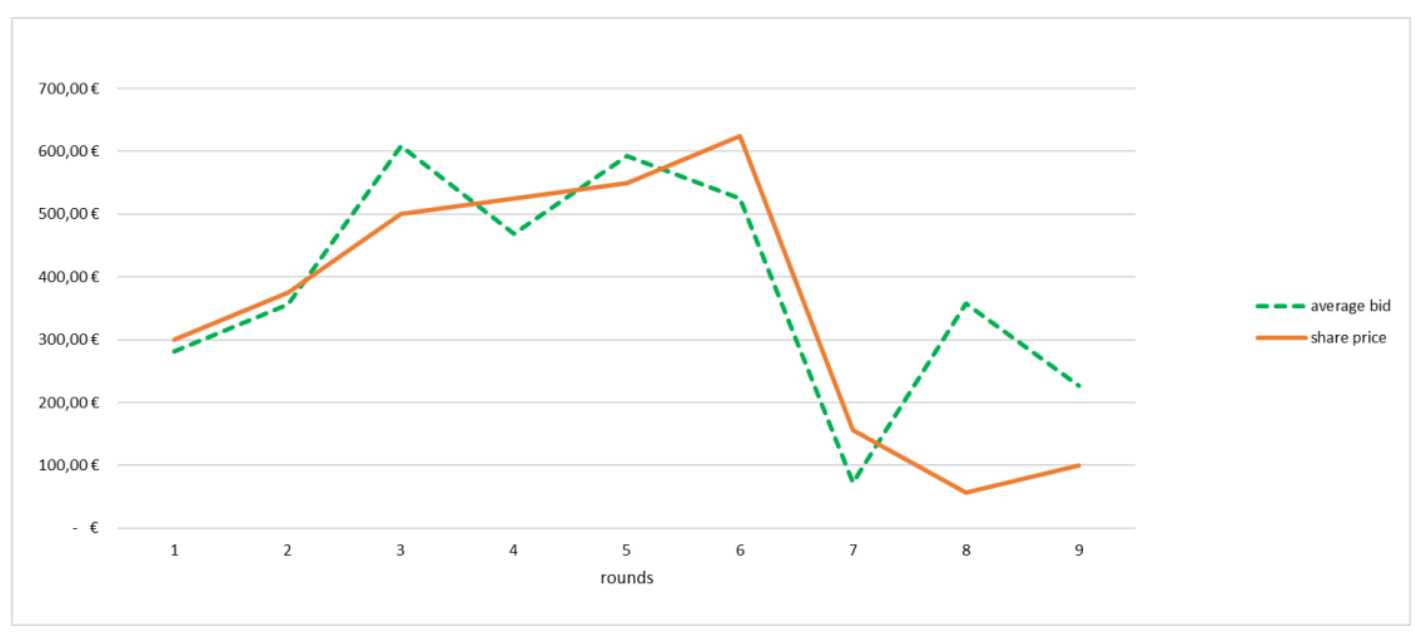

Figure 5. Average bids and share prices (average of all groups)

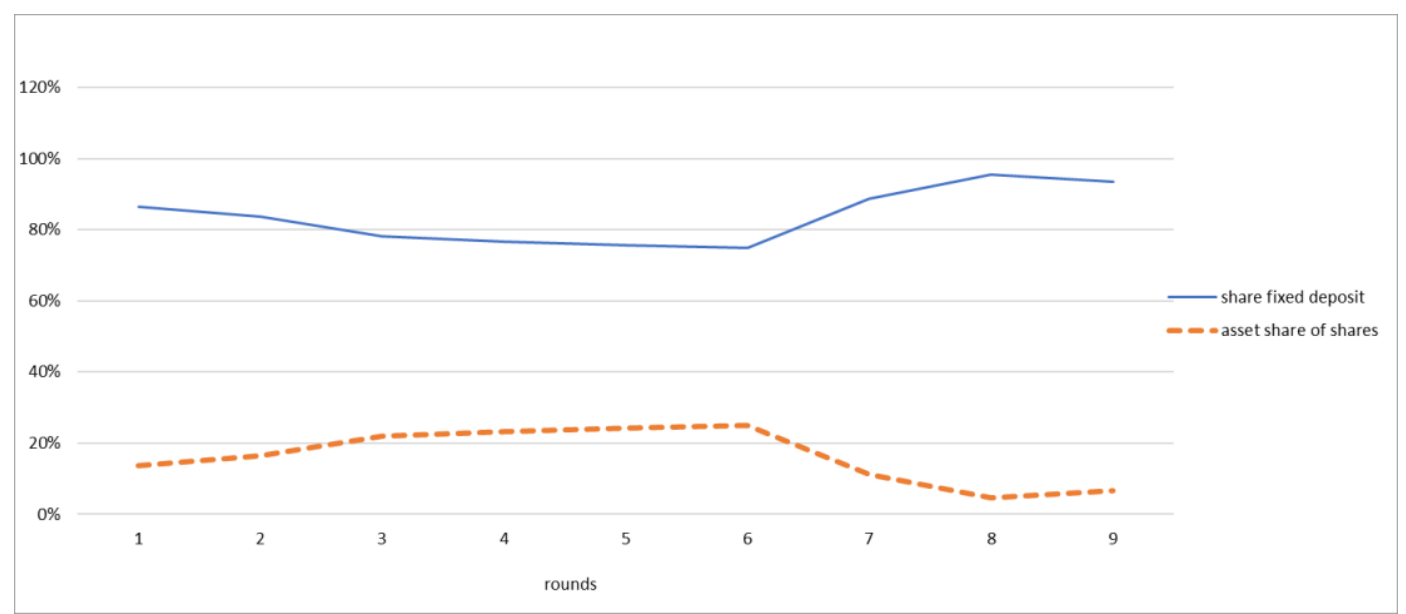

Figure 6. Asset share of shares and fixed deposits

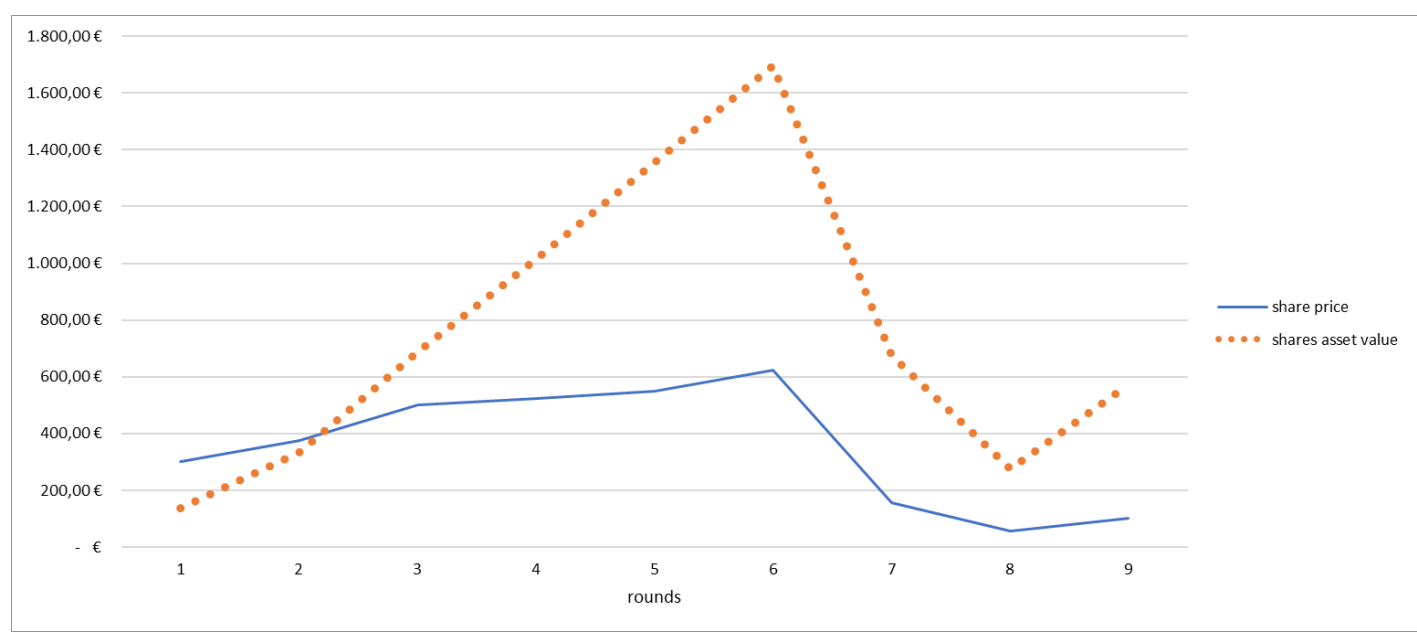

Figure 7. Share prices and the asset value of shares

The buying of the shares seemed to be consistent and rational as the dividends and earnings increased. The price to earning ratio shows that the impact of the lower interest rates compensated the higher share prices (see figure 8) as borrowing cost decreased and thus the earnings increased. 


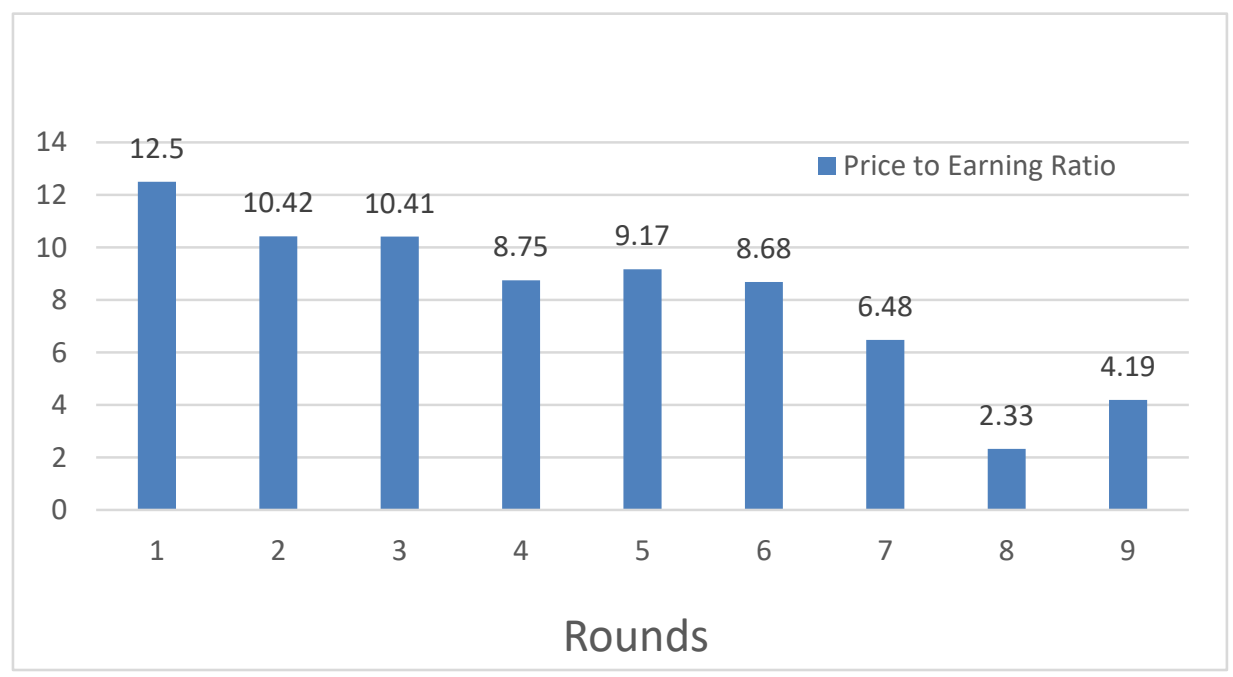

Figure 8. Price to Earning Ratio

\section{Conclusion game $B$}

Our hypothesis was not proven false, as the interest rates influenced the capital allocation according to the portfolio-theory. The students invested in the stocks as assets with higher yields as the interest rate dropped and dividends rose. The higher risk of the shares was not a hindrance. The yield from bonds are the alternative of shares and vice versa. A decrease in interest rate led in the experiment to higher share prices and vice versa. In addition, the interest rates influenced the cost of borrowed capital for the enterprises. Therefore, lower interest rates led to higher profits and dividends.

Share prices were clearly driven by the interest rate reduction, which resulted in higher earnings and dividends. The price to earning ratio is deceptive in that the impact of the lower interest rates compensated the higher share prices even though the profit of the core business activities stayed the same. In our experiments we had an increase in profits of $100 \%$ as a reaction to a $66 \%$ interest rate reduction, thus an elasticity of 1.5 . Thus price to earning ratios are not an adequate pricing tool and cannot help to detect a stock market bubble. The sharp increase in interest rates in round 7 led to a stock market crash due to quick portfolio adjustments. And the crash resulted in a strong decrease of the share asset value.

\section{Final Conclusion}

In our experiments the increase of money supply and the decrease of interest rates had a direct positive impact on share prices. All groups showed similar behavior and the games may be repeated and reviewed by other scientists in the future. Moreover, the sharp increase in interest rates and the stoppage of money supply increase led to a stock market crash due to quick portfolio adjustments. The crash resulted in a strong decrease of the asset value of shares. Therefore, the central banks must keep in mind that the interest rates do not just influence the investments in the real economy. Boom and bust cycles are a real danger of an expansive monetary policy with low interest rates. If there has been an expansive monetary policy or strong interest rate cuts followed by increasing stock process, the exit from this policy has to be slow to prevent a subsequent crash (boom and bust cycle). Central banks have a responsibility for the stock market if they increase the money supply disproportionately to the real production and intervene in the money market or even in the capital market by a QE-policy. The question if it is wise to do so at all has to be discussed separately.

In addition, the measurement of inflation has to be discussed. The inflation measures used by central banks mainly include consumer goods prices and producer prices. Price developments in the financial sector and asset prices are thus systematically hidden by the measurement method. So it is possible that excessive money production is reflected not in rising prices for consumer goods, but in price increases on the stock market or real estate market. If only consumer goods prices are considered, this can lead to unpredictable inflation (Mezger \& Stahl, 2001, Conrad, C. A. \& Stahl, M., 2002).

Experiment B showed that decreasing interest rates encourage risk taking. The portfolio theory was true in our experiments. Interest rate cuts led to a shift towards shares as an alternative asset with higher yield. The higher risk of the shares was not a hindrance. The mechanism "search for yield" took place. The students reacted to the lower interest rates by taking on risk.

Share prices were clearly driven by the interest rate reduction, which resulted in higher earnings and dividends. The 
price to earning ratio is deceptive in that the impact of the lower interest rates compensated the higher share prices even though the profit of the core business activities stayed the same. Thus price to earning ratios are not an adequate pricing tool and cannot help to detect a stock market bubble. The valuation indicators for equities would have to be adjusted for the refinancing costs. Even a smooth price-earnings ratio like that of Shiller (CAPE, Cycle-Adjusted Price Earnings Ratio) could be distorted by a prolonged period of low interest rates.

The results of our experiments show that money supply and interest rates not only influence investments in the real economy, they also have a direct impact on the stock markets and tend to favor speculative bubbles. To avoid a crash the exit from such a policy must be slow. As happened in 1929, crashes can damage the financial system and the real economy. Central banks must take this into account in their monetary policy.

\section{References}

Baks, K., \& Kramer, C. (1999). Global Liquidity and Asset Prices: Measurements: Implications and Spillovers. IMF Working Paper 99/168. https://doi.org/10.5089/9781451858242.001

Black, F. (1987). Business Cycles and Equilibrium. New York: Basil Blackwell.

Campbell, J. Y., \& Ammer, J. (1993). What moves the stock and bond markets? A variance decomposition for long-term asset returns. The Journal of Finance, 48(1), 3-37. https://doi.org/10.1111/j.1540-6261.1993.tb04700.x

Caruana, J. (2013). Hitting the limits of "outside the box" thinking? Monetary policy in the crisis and beyond, Official Monetary and Financial Institutions Forum lecture (Golden Series Lecture), London: Received from https://www.bis.org/speeches/sp130516.htm

Conrad, C. A. (2000). Theorie und Praxis der Speculative Bubbles, In C. A. Conrad \& Stahl, M, (Eds.), Risikomanagement an den internationalen Finanzmärkten, Stuttgart: Schaeffer Poeschel.

Conrad, C. A. (2015). Incentives, Risk and Compensation Schemes: Experimental Evidence on the Importance of Risk Adequate Compensation. Applied Economics and Finance, 2(2), 50-55. https://doi.org/10.11114/aef.v2i4.1053

Conrad, C. A. (2019). The effects on investment behavior of zero interest rate policy, evidence from a roulette experiment. Applied Economics and Finance, 6(4), 18-27. https://doi.org/10.11114/aef.v6i4.4272

Conrad, C. A. (2020). Political Economy. Wiesbaden: Springer-Gabler. https://doi.org/10.1007/978-3-658-30884-1

Conrad, C. A., \& Stahl, M. (2002). Asset-Preise als geldpolitische Zielgröße - das Beispiel der USA. Wirtschaftsdienst, 82(8), 486-493.

De Nicolò, G., Dell'Ariccia, G., Laeven, L., \& Valencia, F. (2010). Monetary Policy and Bank Risk-Taking. IMF Staff Position Note, SDN/10/09. https://doi.org/10.5089/9781455253234.004

Feldstein, M. (2013). The Taper Chase. Project Syndicate, September 30. https://www.project-syndicate.org/commentary/why-the-fed-postponed-the-qe-taper-by-martin-feldstein?barrier=acc esspaylog

Flannery, M. J., \& Protopapadakis, A. A. (2002). Macroeconomic factors do influence aggregate stock returns, Review of Financial Studies, 15(3), 751-782. https://doi.org/10.1093/rfs/15.3.751

Frenk, D. (2011). Review of Irwin and Sanders 2010, OECD Report. In Institute for Agriculture and Trade Policy (Ed.). Excessive Speculation in Agriculture Commodities, Selected writings from 2008-2012, 43-49. Retrieved from http://www.iadb.org/intal/intalcdi/PE/2011/08247.pdf

Grosskettler, H. (1989). Johan Gustav Knut Wicksell. In J. Starbatty (Ed). Klassiker des ökonomischen Denkens II (pp. 191- 210). München: Beck.

Hannoun, H. (2015). Ultra-Low or Negative Interest Rates: What They Mean for Financial Stability and Growth. Speech at the Eurofi High-Level Seminar, Riga, April 22. Received from https://www.bis.org/speeches/sp150424.pdf

Hayek, F. A. (1976). Geldtheorie und Konjunkturtheorie. Reprinting of the original from 1929. Salzburg: Wolfgang Neugebauer.

Hayek, F. A. von (1935). Prices and production ( ${ }^{\text {nd }}$ ed.). Clifton: Kelley (reprint In The Ludwig von Mises Institute (Eds.), Prices \& production and other works. F. A. Hayek on money, the business cycle, and the gold standard. Auburn 2008. https://mises.org/library/prices-and-production.

Homa, K. E., \& Jaffee, D. M. (1971). The Supply of Money and Common Stock Prices. The Journal of Finance, 26(5), 1045-1066. https://doi.org/10.1111/j.1540-6261.1971.tb01747.x

International Monetary Fund. (2000). World economic outlook, Asset Prices and the Business Cycle, Washington. 
Irwin, S. H., \& Sanders, D. R. (2012). Testing the Masters Hypothesis in Commodity Futures Markets. Energy Economics, 34, 256-269. https://doi.org/10.1016/j.eneco.2011.10.008

Ito, T., \& Iwaisako, T. (1995). Explaining Asset Bubbles in Japan. National Bureau of Economic Research, Working Paper 5358. https://doi.org/10.3386/w5358

Kganyago, T., \& Gumbo, V. (2015). An Empirical Study of the Relationship between Money Market Interest Rates and Stock Market Performance: Evidence from Zimbabwe (2009-2013). International Journal of Economics and Financial Issues, 5(3), 638-646.

Lastrapes, W. D. (1998). International evidence on equity prices, interest rates and money. Journal of International Money and Finance, 17(3), 377-406. https://doi.org/10.1016/S0261-5606(98)00012-6

Mezger, M., \& Stahl, M. (2001). Neue Erkenntnisse über Inflation und Finanzkrisen, Orientierungen zur Wirtschaftsund Gesellschaftspolitik der Ludwig-Erhard-Stiftung, 87, 15-22.

Pagan, A., \& Schwert, C. (1990). Testing For Covariance Stationarity in Stock Market Data. Economics Letters, 33(2), 165-170. https://doi.org/10.1016/0165-1765(90)90163-U

Phillips, P., \& Loretan, M. (1990), Testing Covariance Stationarity Under Moment Condition Failure with an Application to Common Stock Returns. Cowles Foundation for Economic Research at Yale University New Haven Conneticut Discussion Paper, 947.

Pícha, V. (2017). Effect of Money Supply on the Stock Market. Acta Universitatis Agriculturae et Silviculturae Mendelianae Brunensis, 65(2), 465-472. https://doi.org/10.11118/actaun201765020465

Rajan, R. G. (2005). Has Financial Development Made the World Riskier? NBER Working Paper No. 11728. https://doi.org/10.3386/w11728

Rigobon, R., \& Sack, B. (2004). The impact of monetary policy on asset prices. Journal of Monetary Economics, 51(8), 1553-1575. https://doi.org/10.1016/j.jmoneco.2004.02.004

Rozeff, M. S. (1974). Money and stock prices: Market efficiency and the lag in effect of monetary policy, Journal of financial Economics, 1(3), 245-302. https://doi.org/10.1016/0304-405X(74)90020-8

Safar, L., \& Siničáková, M. (2017). Money Supply Influence on Gross Domestic Product throughout Stock Markets in United States and European Union. Journal of Applied Economic Sciences, 12(6), 1578-1584.

Schlecker, M. (2014). Kointegrationsanalyse, Stationarität und Augmented-dickey-fuller-Test. Retrieved from http://www.matthias-schlecker.de/kointegrationsanalyse-stationaritaet-und-augmented-dickey-fuller-test

Stiglitz, J. (2016). What's Wrong with Negative Rates?, Project Syndicate, April 13. Retrieved from https://www.project-syndicate.org/commentary/negative-rates-flawed-economic-model-by-joseph-e--stiglitz-2016-0 4? barrier=accesspaylog

Thorbecke, W. (1997). On stock market returns and monetary policy. The Journal of Finance, 52(2), 635-654. https://doi.org/10.1111/j.1540-6261.1997.tb04816.x

Wicksell, K. (1922). Vorlesungen über Nationalökonomie auf Grundlage des Marginalprinzipes: Bd. 2. Geld und Kredit. 1969 Aalen: Scienta (first published Stockholm 1906).

Wicksell, K. (1968). Geldzins und Güterpreise. Eine Studie über den Tauschwert des Geldes bestimmenden Ursachen. Aalen: Scienta (first published Jena 1898).

\section{Copyrights}

Copyright for this article is retained by the author(s), with first publication rights granted to the journal.

This is an open-access article distributed under the terms and conditions of the Creative Commons Attribution license which permits unrestricted use, distribution, and reproduction in any medium, provided the original work is properly cited. 